the way outlined here may be higher than on the slope. For example, $E\left(S_{100}\right)$ values of up to 48.9 isopod species have been recorded from the central Pacific Ocean $^{6}$.

Grassle and Maciolek also suggested that shallow marine environments outbenthic species compared to the deep sea. They cite 200 species as the number expected for large collections from the Georges Bank. In southeastern Australia the fauna is far richer: more than 700 infaunal benthic species in Port Philiip Bay $^{7}$; more than 800 species in $10 \mathrm{~m}^{2}$ of benthos in Bass Strait (unpublished data). This is further evidence that the North Atlantic is not typical of oceanic biodiversity and that further exploration in the little-studied Southern Hemisphere will significantly add to estimates of marine species richness.

Gary C. B. Poore

Department of Crustacea,

Museum of Victoria,

Swanston Street, Melbourne,

Victoria 3000, Australia

George D. F. Wilson

Division of Invertebrate Zoology,

Australian Museum,

PO Box A285, Sydney,

New South Wales 2001,

Australia

MAY REPLIES - Poore and Wilson make an important contribution to discussions of benthic macrofaunal diversity. They emphasize that benthic fauna can vary greatly from place to place, so that estimates of total species numbers based on patterns found in any one location can easily be confounded by different patterns in other locations. Poore and Wilson suggest an overall factor of 20 might be appropriate in extrapolating from known to total benthic faunas, side of the tropics have relatively few

leading to an estimate of around 5 million species. This is ten times my rather conservative guess ${ }^{2}$, but still well below that in Grassle and Maciolek's important and provocative paper ${ }^{1}$ (they estimated a few hundreds of millions, but scaled it back to 10 million or so to express their view that species numbers are likely to be lower on the floors of ocean basins than on continental shelves or midslopes; note that Poore and Wilson believe, to the contrary, that species richness may be higher in ocean basins).

Poore and Wilson use $E\left(S_{100}\right)$, the average number of different species found in a sample of 100 individuals, as a guide to species numbers, inferring that more species are present when $E\left(S_{100}\right)$ is higher. But $E\left(S_{100}\right)$ measures evenness, not species richness. Very often a larger value of this index will indicate more species are present. But it is perfectly possible for two communities to have very different values of $E\left(S_{100}\right)$, even though both have the same total of species (just as two countries with similar total populations and total wealth can have the wealth distributed in very different ways, from egalitarian to feudal extremes).

Robert M. May

Department of Zoology,

University of Oxford,

South Parks Road,

Oxford OX1 3PS, UK

1. Grassle, J. F. \& Maciolek, N. J. Am. Nat. 139, 313-341 (1992).

2. May, R. Nature 357, $278-279$ (1992).

3. Svavarsson, J., Brattegard, T. \& Strömberg, J.-0. Prog. Oceanogr. 24, 297-310 (1990).

4. Hessler, R. R. \& Wilson, G. D. F. in Evolution, Time and Space: The Emergence of the Biosphere (eds Sims, R. W., Price, J. H. \& Whalley, P. E. S.) 227-254 (Academic, London, 1983).

5. Scheltema, A. H. Bull. Mar. Sci. 47, 50-61 (1990)

6. Thistle, D. \& Wilson, G. D. F. Deep-Sea Res. 34, 73-87 (1987)

Poore, G. C. B., Rainer, S. F., Spies, R. B. \& Ward, E.

Fish. Wildl. Pap., Vict. 7, 1-78 (1975).

\section{Solar output and global warming}

SIR - The debate as to whether solar variability is a significant cause of the rise in global mean surface air temperature $^{1-4}$ has been based on data analysis. Although theoretical mechanisms have been postulated, they are difficult to test because of the lack of historical data on the variability of the solar output.

However, there is a terrestrial parameter which is highly sensitive to variations in the solar ultraviolet radiation - the atmospheric semi-diurnal tide ${ }^{5}$. Unlike the ocean tides, the atmospheric tides are predominantly forced by solar heating ${ }^{6}$. In particular, the semi-diurnal (12-hour) tide is driven by absorption of ultraviolet radiation in the stratosphere and thus is sensitive to wavelengths where solar output varies significantly ${ }^{7}$.
Historical data on the amplitude of the atmospheric semi-diurnal tide could therefore provide an indication of the magnitude of solar variability with sunspot cycle length.

Such a dataset is available as the semi-diurnal tide dominates the variations in atmospheric pressure in the tropics ${ }^{6}$. Hourly pressure data (required to calculate the tide) over many decades are available for various tropical meteorological stations.

I would like to suggest that someone who can access these data calculates the variation in the annual mean semidiurnal tide in the tropics over the past 100 years. According to the above theory, this should show whether or not the solar ultraviolet output varies with the sunspot cycle length. A negative result would imply that it is highly unlikely that the global mean temperature depends on this cycle length.

Nell S. Cooper

104 Westhall Road,

Warlingham,

Surrey CR6 9HD, UK

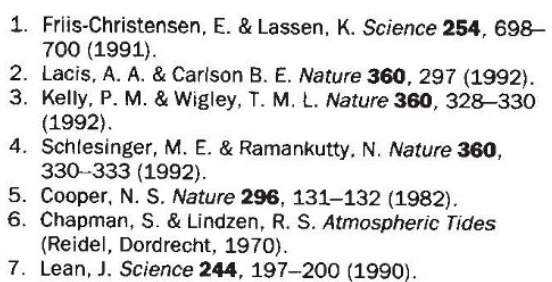

\section{Purity of nature?}

SIR - The description by G. H. Gonnet and S. A. Benner (Nature 361, 121; 1993) of their search of the one-letter coded sequences of proteins for long English words stirred memories of 32 years ago when I was writing a review on peptides and proteins for the Annual Reports of the Chemical Society. The one-letter code had recently been introduced by the late Professor F. Šrm of the Czech Academy of Sciences. Not many protein sequences were then known but they were clearly going to appear at an ever-increasing rate.

I enquired of the editor if I might use Šrm's code to save space; permission was withheld on the grounds that obscene sequences might be forthcoming. I wrote to Professor Šorm telling him of the decision and my frustration. He replied that he had written out all the sequences known at that time and had not found any sequence that could be construed as obscene. With tongue in cheek, he attributed this to the purity of nature.

In fact, with a characteristic versatility, he displayed a good working knowledge of the English vernacular and avoided the use of letters such as $\mathrm{u}$, $\mathrm{o}$ and $\mathrm{b}$, which might have given rise to obscene sequences. There are, however, some indelicate words that can be constructed from the partial alphabet used by Šorm.

With the immense databank of protein sequences now available, it would be interesting to know if Šorm's attribution of verbal purity to nature is really true. Whatever the answer, it appears from the two recondite examples cited by Gonnet and Benner that nature indulges in sesquipedalianism. Perhaps this is a reflection of the tendency of naturally occurring macromolecules to contain redundant sequences.

\section{T. Elmore}

Dyson Perrins Laboratory,

South Parks Road,

OXford OX1 3QY, UK

NATURE · VOL 361 - 18 FEBRUARY 1993 